\title{
EFFECT OF SOLUTION pH AND TEMPERATURE ON PHENOL ADSORPTION ONTO CARBONIZED RICE HUSK CHEMICALLY ACTIVATED WITH PHOSPHORIC ACID
}

\author{
YAHAYA S. MOHAMMAD ${ }^{* 1,3}$, MOHAMMED U. GARBA ${ }^{2}$, \\ MUHAMMAD A. MUHAMMAD ${ }^{3}$, YAKUBU AZEH ${ }^{3}$, SULEIMAN Y. BAGIREI ${ }^{1}$ \\ ${ }^{I}$ Department of Food Science and Technology, IBB University, Lapai, Nigeria \\ ${ }^{2}$ Department of Chemical Engineering, F.U.T., Minna, Nigeria \\ ${ }^{3}$ Department of Chemistry, IBB University, Lapai, Nigeria
}

\begin{abstract}
Operating conditions such as $\mathrm{pH}$ and temperature are important factors that influence the performance of activated carbon and solute uptake in adsorption process. Thus, this research work was aimed at studying the effect of solution $\mathrm{pH}$ and temperature on phenol adsorption onto rice husk activated carbon. Results obtained showed that when $\mathrm{pH}$ was increased from 2 to 4, adsorption capacity and removal efficiency increased, and thereafter, decreased progressively with additional increase in $\mathrm{pH}$. Results also showed that when temperature was increased from 30 to $50{ }^{\circ} \mathrm{C}$ adsorption capacity and removal efficiency decreased. Therefore, this study has established that the optimum solution $\mathrm{pH}$ for adsorption of phenol onto phosphoric acid modified rice husk activated carbon is 4 , and better performance of the adsorption process was occurred at lower solution temperatures.
\end{abstract}

Keywords: phenol, adsorption capacity, rice husk, concentration, equilibrium

\section{INTRODUCTION}

Adsorption is a process involving a solid phase and a liquid/gas phase containing dissolved species to be detached where the dissolved species migrate from the liquid/gas phase and form an attachment with the solid phase by different mechanisms as a result of stronger affinity. Adsorption using agricultural wastes as activated carbon for removal of contaminants from wastewater is receiving great attention due to economic and environmental concerns. Phenol is an organic compound that is continuously being generated in industries such as petroleum refinery as wastewater contaminant thereby necessitating treatment before eventual disposal into receiving bodies while incidentally, rice husk is a potential source of activated carbon that is locally available in Nigeria but underutilized and thereby constituting solid waste menace in the environment [1-7].

Reports on adsorption of solute onto activated carbon in literature have demonstrated that performance is largely dependent on the characteristics of the adsorbent (surface area, pore size distribution and surface functional groups), properties of the solute (molecular size, solubility, pKa and electron distribution) and operating conditions such as $\mathrm{pH}$ and temperature $[8,9]$. Solution $\mathrm{pH}$ is an important factor in adsorption process because it affects the properties of solute and adsorbent such as type and ionic state of functional groups, degree of ionization of the solute contained in solution, dissociation of functional groups existing on the active sites of the activated carbon and chemistry of the solute contained in solution [10-15].

\footnotetext{
* Corresponding author, email: yahsaymoh@yahoo.co.uk

(C) 2021 Alma Mater Publishing House
} 
The three possible mechanisms of complex interplay of electrostatic and dispersion interactions through which phenol adsorption onto activated carbon can occur are: (i) complex formation of electron donor-acceptor at the surface of adsorbent where the electron donor is the oxygen of surface carbonyl group and the electron receptor is the phenol aromatic ring, (ii) formation of hydrogen bond, and (iii) $\pi-\pi$ dispersion interaction between aromatic ring of the molecules of phenol and $\pi$ electrons delocalized on the graphene layers of adsorbent surfaces [16-19]. However, mechanisms 1 and 3 cannot occur at the same time as the presence of one rule out the possibility of the other. Solution temperature also has considerable effect on the adsorption process. Therefore, the objective of this study was to investigate the effect of solution $\mathrm{pH}$ and temperature on adsorption of phenol onto carbonized rice husk chemically activated with phosphoric acid.

\section{EXPERIMENTAL SETUP}

\subsection{Materials}

The materials used during the experimentation include furnace, ceramic flat surface, oven drier, de-ionized water, measuring cylinder, $\mathrm{pH}$ meter, digital weighing balance, conical flask, magnetic stirrer (Jenway 1000 Hotplate and Stirrer), micro filter $(0.2 \mu \mathrm{m})$, syringe, centrifuge (Horizon Clinispin 842VES), UV spectrophotometer (Jenway 6404UV), quartz cuvettes. The agricultural material used in this study was rice husk and the reagents used were phosphoric acid, nitric acid, sodium hydroxide and phenol, all of which were of analytical grade.

\subsection{Production of adsorbent/activated carbon}

The source material for the production of activated carbon was rice husk which was obtained from National Cereal Research Institute (NCRI), Badeggi, Nigeria. After collection, it was cleaned with distilled water for removal of any associated dirt and impurity. Thereafter, the cleaned rice husk was oven-dried at $100{ }^{\circ} \mathrm{C}$ for $24 \mathrm{~h}$. The carbonization process was carried out by putting the oven-dried rice husk on a ceramic plate, then placing it inside a furnace where it was heated at a rate of $20-25{ }^{\circ} \mathrm{C} / \mathrm{min}$ to an optimum temperature of $441.46{ }^{\circ} \mathrm{C}$ and residence time of $1 \mathrm{~h}$, after which the carbonized residue was collected and cooled at room temperature. Furthermore, the chemical modification process was carried out by activating the carbonized rice husk with $1 \mathrm{M} \mathrm{H}_{3} \mathrm{PO}_{4}$ for $3 \mathrm{~h}$ at impregnation ratio of 2:1 representing volume $(m L)$ of acid to mass $(g)$ of rice husk, after which it was oven-dried at $200{ }^{\circ} \mathrm{C}$ overnight in order to guarantee proper drying. The material was then removed from the oven, cooled at room temperature for $2 \mathrm{~h}$ and then cleaned with distilled water to adjust the $\mathrm{pH}$ to 7.0 and again oven-dried overnight at $100^{\circ} \mathrm{C}[20,21]$.

\subsection{Adsorption experiment}

The batch mode adsorption experiment was conducted in Multi-User Laboratory of Ahmadu Bello University, Zaria, Nigeria, under the optimum operating condition developed from our preliminary study, that is, initial concentration of $40.61 \mathrm{mg} / \mathrm{L}$ and adsorbent dosage of $4 \mathrm{~g}$ [22]. Thus, $4 \mathrm{~g}$ of the activated carbon was added to $100 \mathrm{ml}$ of $40.61 \mathrm{mg} / \mathrm{L}$ phenol concentration in a $250 \mathrm{~mL}$ conical flask and was placed on a magnetic stirrer at $150 \mathrm{rpm}$ for $90 \mathrm{~min}$ at a known solution $\mathrm{pH} /$ temperature. Thereafter, samples were collected and centrifuged at $3000 \mathrm{rpm}$ for $20 \mathrm{~min}$, after which the supernatant solution was taken from the centrifuge by means of decantation and then filtered with a micro filter attached to a $5 \mathrm{~mL}$ syringe. After each use, the micro filter was backwashed with de-ionized water using a $50 \mathrm{~mL}$ syringe. The procedure outlined above was carried out at solution $\mathrm{pH}$ of 2 , 4, 6, 8 and 10 and the $\mathrm{pH}$ was adjusted by adding a few drops of $\mathrm{HNO}_{3}$ or $\mathrm{NaOH}$. It was also carried out at solution temperatures of 30,40 and $50{ }^{\circ} \mathrm{C}$ on a hot plate magnetic stirrer [6, 22-25]. The concentration of phenol in each sample filtrate was determined using UV spectrophotometer set at wavelength of $270 \mathrm{~nm}$ absorbance. Prior to analysis, a technical calibration curve was prepared and it was linear over the concentration range used. Therefore, un-adsorbed phenol concentration in the filtrate was determined by interpolation using the calibration curve.

\subsection{Determination of Adsorption Capacity and Removal Efficiency}

Equation (1) and (2) were used to determine the adsorption capacity at equilibrium [26, 27] and removal efficiency [28-30] respectively:

$$
\begin{aligned}
& q_{e}=\frac{\left(C_{o}-C_{e}\right) V}{m} \\
& R E=\frac{\left(C_{o}-C_{e}\right)}{C_{o}} \times 100
\end{aligned}
$$




\subsection{Determination of Ionic Fraction}

Equation (3) was used to determine the ionic fraction of phenolate [31, 32]:

$$
\varphi_{\text {ions }}=\frac{1}{1+10^{(p K a-p H)}}
$$

where $q_{e}$ is equilibrium adsorption capacity $(\mathrm{mg} / \mathrm{g}) ; C_{o}=$ initial concentration of the solute $(\mathrm{mg} / \mathrm{L})$; $C_{e}=$ concentration of solute at equilibrium $(\mathrm{mg} / \mathrm{L}) ; V=$ volume of the solution $(\mathrm{L}) ; m=$ mass of adsorbent used $(\mathrm{g}) ; R E=$ removal efficiency $(\%) ; \phi_{\text {ions }}=$ ionic fraction of phenolate; $p K_{a}=$ acid dissociation/ionization constant.

\section{RESULTS AND DISCUSSION}

\subsection{Effect of solution $\mathbf{p H}$}

The effect of solution $\mathrm{pH}$ on adsorption capacity and removal efficiency of phenol adsorption onto rice husk activated carbon are presented in Figures 1 and 2.

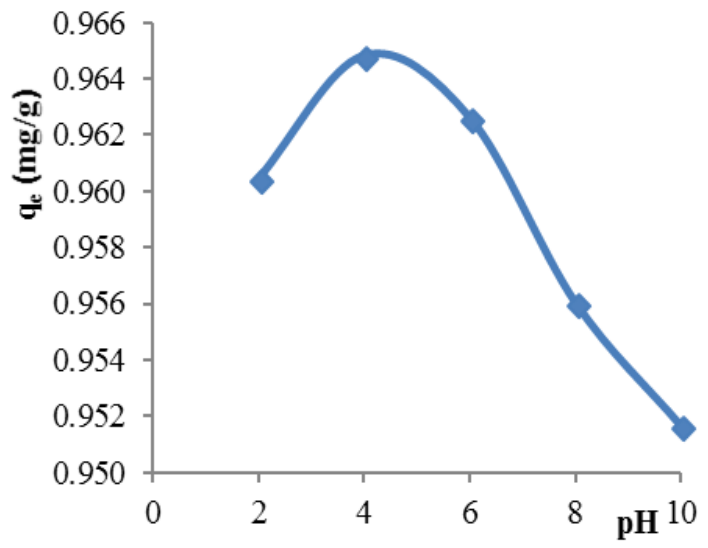

Fig. 1. Effect of $\mathrm{pH}$ on adsorption capacity.

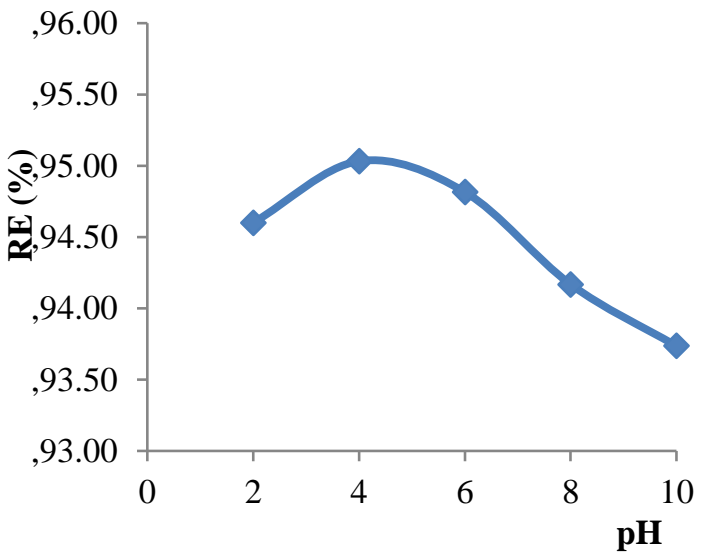

Fig. 2. Effect of $\mathrm{pH}$ on removal efficiency.

It was observed in Figure 1 that when $\mathrm{pH}$ was increased from 2 to 4, adsorption capacity increased from 0.960 to $0.965 \mathrm{mg} \cdot \mathrm{g}^{-1}$ and thereafter, as the $\mathrm{pH}$ was increased further, adsorption capacity was observed to decrease progressively. Figure 2 also shows that removal efficiency increased from 94.6 to $95.03 \%$ as $\mathrm{pH}$ was increased from 2 to 4 and thereafter, as the $\mathrm{pH}$ was increased further, removal efficiency was also observed to decrease progressively. Therefore, the optimum $\mathrm{pH}$ for phenol adsorption was taken as 4 . The pKa of phenol, a weak acid is 9.89 and as a result phenol is usually dissociated at $\mathrm{pH}>\mathrm{pKa}$. In a phenol solution, when $\mathrm{pH}<\mathrm{pKa}$ of phenol, the molecular form of phenol are the predominating species which are either neutral or positively charged. Therefore, maximum adsorption performance is observed at low $\mathrm{pH}$ because phenol is not dissociated and the driving force for adsorption is dispersion which is based on $\pi-\pi$ interaction between the $\pi$ electrons delocalized on the activated carbon graphene layers and the aromatic ring of the phenol molecules [17, 33-37].

But when $\mathrm{pH}>\mathrm{pKa}$ of phenol, the ionic form, which is a consequence of the aromatic ring been partially negatively charged by means of the hydroxyl group ionization, is the predominating specie. This is confirmed in Table 1 which revealed that the ionic fraction of the phenolate ions, $\phi_{\text {ions }}$ increases as the $\mathrm{pH}$ was increased. Therefore, the major mechanism is electrostatic interaction which may be attractive or repulsive. Thus, the observed progressive decrease in adsorption performance could be a consequence of electrostatic repulsion between phenolate ions and negatively charged activated carbon surfaces; or phenolate ions and already adsorbed ones [8, 17, 31, 38]. In addition, these phenolate ions are more soluble in aqueous solution and the stronger adsorbate-water molecule must be overcome before adsorption takes place [33]. Another possible reason for the observed reduction in adsorption performance is the resultant large quantity of hydroxyl ions formed, which via physical adsorption, lead to additional negative charges on the surface of the activated carbon thus, establishing competitive adsorption between hydroxyl and phenolate ions [39-42]. Similar trend was also reported in the literature [32, 38, 43-45]. 
Table 1. Ionic fraction of phenolate at different $\mathrm{pH} \mathrm{pKa}$ of phenol, 9.89

\begin{tabular}{|c|c|c|c|c|c|}
\hline $\mathrm{pH}$ & 2 & 4 & 6 & 8 & 10 \\
\hline$\phi_{\text {ions }}$ & $1.288 \times 10^{-8}$ & $1.288 \times 10^{-6}$ & $1.288 \times 10^{-4}$ & $1.272 \times 10^{-2}$ & $5.63 \times 10^{-1}$ \\
\hline
\end{tabular}

\subsection{Effect of solution temperature}

The effect of solution temperature on adsorption capacity and removal efficiency of phenol adsorption onto rice husk activated carbon is as presented in Figures 3 and 4.

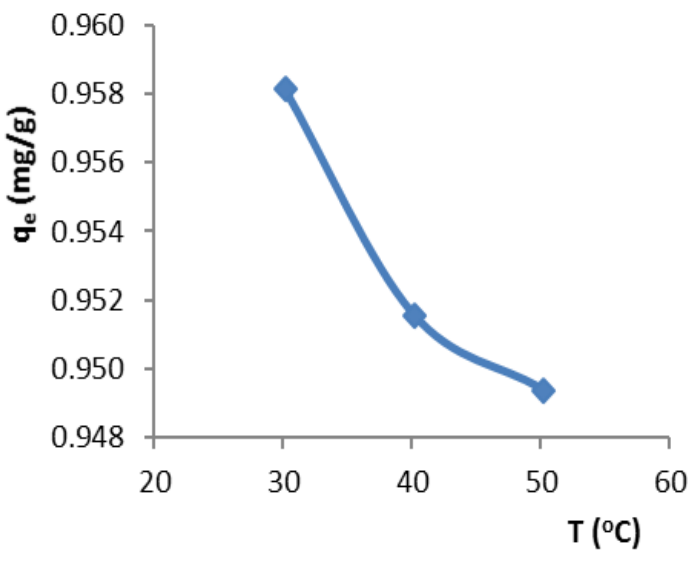

Fig. 3. Effect of temperature on adsorption capacity.

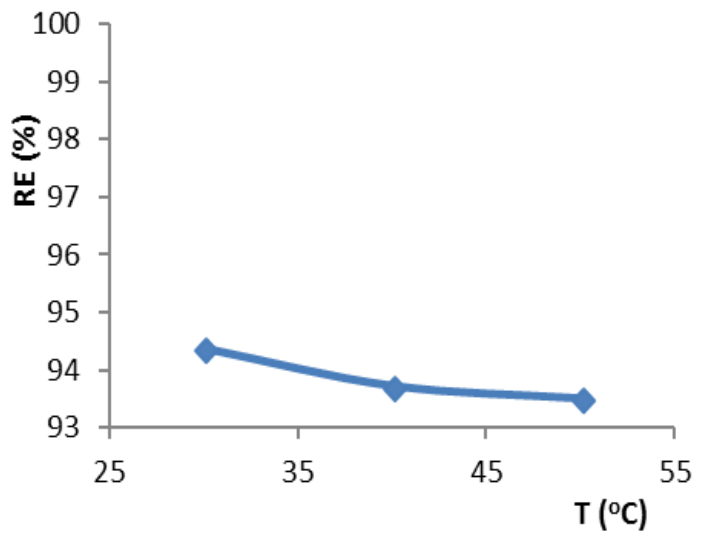

Fig. 4. Effect of temperature on removal efficiency.

It was observed in Figure 3 that when temperature was increased from 30 to $50{ }^{\circ} \mathrm{C}$ adsorption capacity decreased from 0.958 to $0.948 \mathrm{mg} . \mathrm{g}^{-1}$. Figure 4 also shows that removal efficiency decreased from 94.38 to $93.52 \%$ as the temperature was increased from 30 to $50{ }^{\circ} \mathrm{C}$ and according to $[46,47]$, this indicates less chemical interaction between the phenol molecules and the surface of the active carbons. It also implies that low temperatures favour higher adsorption capacity and removal efficiency most probably because adsorption process is exothermic. This observation is in agreement with the trend reported by Ozturk and Kavak [48]. The observed decrease in adsorption performance as the solution temperature increases could be attributed to the weakening of the physical bonding between phenol molecules and active sites of the activated carbon or the increased solubility of phenol molecules which enabled stronger interaction force between phenol molecules and solvent than phenol molecules and active sites of activated carbon [49].

\section{CONCLUSIONS}

This study has demonstrated that increase in solution $\mathrm{pH}$ from 2 to 4 has increasing effect on adsorption capacity and thereafter, further increase in $\mathrm{pH}$ results in progressive decrease in adsorption capacity. Also, removal efficiency was observed to increase as $\mathrm{pH}$ was increased from 2 to 4 and thereafter, decreases progressively as the $\mathrm{pH}$ was increased further. The study also demonstrated that increase in temperature has a decreasing effect on adsorption capacity and removal efficiency. Therefore, the optimum solution $\mathrm{pH}$ for adsorption of phenol onto rice husk activated carbon modified with phosphoric acid has been established as 4 . In addition, better performance of the adsorption process was noted to occur at lower solution temperatures

\section{REFERENCES}

[1] Miao, Q., Tang, Y., Xu, J., Liu, X., Xiao, L., Chen, Q., Activated carbon prepared from soybean straw for phenol adsorption, Journal of the Taiwan Institute of Chemical Engineers, vol. 44, 2013, p. 458-465.

[2] Mohammad, Y.S., Shaibu-Imodagbe, E.M., Igboro, S.B., Giwa, A., Okuofu, C.A., Adsorption of phenol from refinery wastewater using rice husk activated carbon, Iranica Journal of Energy \& Environment, vol. 5, no. 4, 2014, p. 393-399.

[3] Faraji, H., Mohamadi, A.A., Soheil, A., Hamid, R., Mahvi, A.H., Kinetics and equilibrium studies of the removal of blue basic 41 and methylene blue from aqueous solution using rice stems, Iranian Journal of Chemistry and Chemical Engineering, vol. 34, no. 3, 2015, p. 33-42. 
[4] Mohammad, Y.S., Shaibu-Imodagbe, E.M., Igboro, S.B., Giwa, A., Okuofu, C.A., Isotherms, kinetics and thermodynamics of phenol adsorption onto rice husk activated carbon, Leonardo Electronic Journal of Practices and Technologies, vol. 26, 2015, p. 115-128.

[5] Naseri, A., Barati, R., Rasoulzadeh, F., Bahram, M., Studies on adsorption of some organic dyes from aqueous solution onto graphene nanosheets, Iranian Journal of Chemistry and Chemical Engineering, vol. 34, no. 2, 2015 , p. 51-60.

[6] Shi, Z., Zou, P., Guo, M., Yao, S., Adsorption equilibrium and kinetics of lead ion onto synthetic ferrihydrites, Iranian Journal of Chemistry and Chemical Engineering, vol. 34, no. 3, 2015, p. 25-32.

[7] Xu, H., Liu, D., He, L., Liu, N., Ning, G., Adsorption of copper (II) from a wastewater effluent of electroplating industry by poly(ethyleneimine)-functionalized silica, Iranian Journal of Chemistry and Chemical Engineering, vol. 34, no. 2, 2015, p. 73-81.

[8] Liu, Q-S., Zheng, T., Wang, P., Jiang, J-P., Li, N., Adsorption isotherm, kinetic and mechanism studies of some substituted phenols on activated carbon fibers, Chemical Engineering Journal, vol. 157, 2010, p. 348-356.

[9] Sych, N.V., Trofymenko, S. I., Poddubnaya, O.I., Tsyba, M.M., Sapsay, V.I., Klymchuk, D.O., Puziy, A.M., Porous structure and surface chemistry of phosphoric acid activated carbon from corncob, Applied Surface Science, vol. 261, 2012, p. 75-82.

[10] Imamoglu, M., Tekir, O., Removal of copper (II) and lead (II) ions from aqueous solutions by ad sorption on activated carbon from a new precursor hazelnut husks, Desalination, vol. 228, 2008, p. 108-113.

[11] Demirbas, E., Dizge, N., Sulak, M.T., Kobya, M., Adsorption kinetics and equilibrium of copper from aqueous solutions using hazelnut shell activated carbon, Chemical Engineering Journal, vol. 148, 2009, p. 480-487.

[12] Wang, L., Zhang, J., Zhao, R., Li, C., Li, Y., Zhang, C., Adsorption of basic dyes on activated carbon prepared from polygonum orientale linn: equilibrium, kinetic and thermodynamic studies, Desalination, vol. 254, 2010 , p. 68-74.

[13] Chakraborty, S., Chowdhury, S., Saha, P.D., Adsorption of crystal violet from aqueous solution onto NAOHmodified rice husk, Carbohydrate Polymers, vol. 86, 2011, p. 1533-1541.

[14] Chowdhury, S., Mishra, R., Saha, P., Kushwaha, P., Adsorption thermodynamics, kinetics and isosteric heat of adsorption of malachite green onto chemically modified rice husk, Desalination, vol. 265, 2011, p. 159-168.

[15] Njoku, V.O., Hameed, B.H., Preparation and characterization of activated carbon from corncob by chemical activation with $\mathrm{H}_{3} \mathrm{PO}_{4}$ for 2,4-dichlorophenoxyacetic acid adsorption, Chemical Engineering Journal, vol. 173, 2011, p. 391-399.

[16] Girods, P., Dufour, A., Fierro, V., Rogaume, Y., Rogaume, C., Zoulalian, A., Celzard, A., Activated carbons prepared from wood particleboard wastes: characterization and phenol adsorption capacities, Journal of Hazardous Materials, vol. 166, 2009, p. 491-501.

[17] Nabais, J.M.V., Gomes, J.A., Suhas Carrott, P.J.M., Laginhas, C., Roman, S., Phenol removal onto novel activated carbons made from lignocellulosic precursors: influence of surface properties, Journal of Hazardous Materials, vol. 167, 2009, p. 904-910.

[18] El-Naas, M.H., Al-Zuhair, S., Alhaija, M.A., Removal of phenol from petroleum refinery wastewater through adsorption on date-pit activated carbon, Chemical Engineering Journal, vol. 162, 2010, p. 997-1005.

[19] Lorenc-Grabowska, E., Gryglewicz, G., Diez, M.A., Kinetics and equilibrium study of phenol adsorption on nitrogen-enriched activated carbons, Fuel, vol. 114, 2013, p. 235-243.

[20] Mohammad, Y.S., Shaibu-Imodagbe, E.M., Igboro, S.B., Giwa, A., Okuofu, C.A., Application of low-cost adsorbent in the treatment of samaru stream water, Journal of Engineering Studies and Research, vol. 20, no. 4, 2014, p. 61-65.

[21] Mohammad, Y.S., Shaibu-Imodagbe, E.M., Igboro, S.B., Giwa, A., Okuofu, C.A., Effect of phosphoric acid modification on characteristics of rice husk activated carbon, Iranica Journal of Energy \& Environment, vol. 6, no. 1, 2015, p. 20-25.

[22] Mohammad, Y.S., Shaibu-Imodagbe, E.M., Igboro, S.B., Giwa, A., Okuofu, C.A., Modeling and optimization for production of rice husk activated carbon and adsorption of phenol, Journal of Engineering, vol. 2014, 2014 , p. $1-10$.

[23] Hameed, B.H., Mahmoud, D.K., Ahmad, A.L., Equilibrium modelling and kinetic studies on the adsorption of basic dye by a low-cost adsorbent: coconut (cocos nucifera) bunch waste, Journal of Hazardous Materials, vol. 158,2008 , p. 65-72.

[24] Srivastava, V.C., Mall, I.D., Mishra, I.M., Removal of cadmium (II) and zinc (II) metal ions from binary aqueous solution by rice husk ash, Colloids and Surfaces A: Physicochem. Eng. Aspects, vol. 312, 2008, p. 172184.

[25] Salvador, F., Martin-Sanchez, N., Sanchez-Montero, M.J., Montero, J., Izquierdo, C., Regeneration of activated carbons contaminated by phenol using supercritical water, Journal of Supercritical Fluids, vol. 74, 2013, p. 1-7. 
[26] Karaca, S., Gurses, A., Acıkyıldız, M., Ejder, M., Adsorption of cationic dye from aqueous solutions by activated carbon, Microporous and Mesoporous Materials, vol. 115, 2008, p. 376-382.

[27] Li, Y., Du, Q., Liu, T., Peng, X., Wang, J., Sun, J., Comparative study of methylene blue dye adsorption onto activated carbon, graphene oxide and carbon nanotubes, Chemical Engineering Research and Design, vol. 91, 2013, p. 361-368.

[28] Garg, U., Kaur, M.P., Jawa, G.K., Sud, D., Garg, V.K., Removal of cadmium (II) from aqueous solutions by adsorption on agricultural waste biomass, Journal of Hazardous Materials, vol. 154, 2008, p. 1149-1157.

[29] Saad, S.A., Isa, K.M. D., Bahari, R., Chemically modified sugarcane bagasse as a potentially low-cost biosorbent for dye removal, Desalination, vol. 264, 2010, p. 123-128.

[30] Lo, S-F., Wang, S.-Y., Tsai, M.-J., Lin, L.-D., Adsorption capacity and removal efficiency of heavy metal ions by moso and ma bamboo activated carbons, Chemical Engineering Research and Design, vol. 90, 2012 , p. 1397-1406.

[31] Singh, K.P., Malik, A., Sinha, S., Ojha, P., Liquid-Phase adsorption of phenols using activated carbons derived from agricultural waste material, Journal of Hazardous Materials, vol. 150, 2008, p. 626-641.

[32] Lazo-Cannata, J.C., Nieto-Marquez, A., Jacoby, A., Paredes-Doig, A.L., Romero, A., Sun-Kou, M.R., Valverde, J.L., Adsorption of phenol and nitrophenols by carbon nanospheres: effect of $\mathrm{pH}$ and ionic strength, Separation and Purification Technology, vol. 80, 2011, p. 217-224.

[33] Busca, G., Berardinelli, S., Resini, C., Arrighi, L., Technologies for the removal of phenol from fluid streams: a short review of recent developments, Journal of Hazardous Materials, vol. 160, 2008, p. 265-288.

[34] Hameed, B.H., Rahman, A.A., Removal of phenol from aqueous solutions by adsorption onto activated carbon prepared from biomass material, Journal of Hazardous Materials, vol. 160, 2008, p. 576-581.

[35] Stavropoulos, G.G., Samaras, P., Sakellaropoulos, G.P., Effect of activated carbons modification on porosity, surface structure and phenol adsorption, Journal of Hazardous Materials, vol. 151, 2008, p. 414-421.

[36] Soto, M.L., Moure, A., Dominguez, H., Parajo, J. C., Recovery, concentration and purification of phenolic compounds by adsorption: a review, Journal of Food Engineering, vol. 105, 2011, p. 1-27.

[37] Nouha, S., Souad, N., Abdelmottalab, O., Enhanced adsorption of phenol using alkaline modified activated carbon prepared from olive stones, Journal of Chilean Chemical Society, vol. 64, no. 1, 2019, p. 4352-4359.

[38] Blanco-Martinez, D.A., Giraldo, L., Moreno-Pirajan, J.C., Effect of the pH in the adsorption and in the immersion enthalpy of monohydroxylated phenols from aqueous solutions on activated carbons, Journal of Hazardous Materials, vol. 169, 2009, p. 291-296.

[39] Beker, U., Ganbold, B., Dertli, H., Gulbayir, D.D., Adsorption of phenol by activated carbon: influence of activation methods and solution pH, Energy Conversion and Management, vol. 51, 2010, p. 235-240.

[40] Wang, L., Application of activated carbon derived from 'waste' bamboo culms for the adsorption of azo disperse dye: kinetic, equilibrium and thermodynamic studies, Journal of Environmental Management, vol. 102, 2012, p. 79-87.

[41] Shah, J.A., Butt, T.A., Mirza, C.R., Shaikh, A.J., Khan, M.S., Arshad, M., Phosphoric acid activated carbon from Melia azedarach waste sawdust for adsorptive removal of reactive orange 16: equilibrium modelling and thermodynamic analysis, Molecules, vol. 25, 2020, 2118.

[42] Awe, A.A., Opeolu, B.O., Fatoki, O.S., Ayanda, O.S., Jackson, V.A., Snyman, R., Preparation and characterization of activated carbon from Vitis vinifera leaf litter and its adsorption performance for aqueous phenanthrene, Applied Biological Chemistry, vol. 63, 2020, p. 1-12.

[43] Ahmaruzzaman, M.D., Adsorption of phenolic compounds on low-cost adsorbents: A review, Advances in Colloid and Interface Science, vol. 143, 2008, p. 48-67.

[44] Srihari, V., Das, A., Comparative studies on adsorptive removal of phenol by three agro-based carbons: equilibrium and isotherm studies, Ecotoxicology and Environmental Safety, vol. 71, 2008, p. 274-283.

[45] Labied, R., Benturki, O., Hamitouche, A.E., Donnot, A., Adsorption of hexavalent chromium by activated carbon obtained from a waste lignocellulosic material (Ziziphus jujuba cores): kinetic, equilibrium, and thermodynamic study, Adsorption Science and Technology, vol. 36, no. 3-4, 2018, p. 1066-1099.

[46] Kennedy, L.J., Vijaya, J.J., Kayalvizhi, K., Sekaran, G., Adsorption of phenol from aqueous solutions using mesoporous carbon prepared by two-stage process, Chemical Engineering Journal, vol. 132, 2007, p. 279-287.

[47] Azeez, L., Adejumo, A.L., Asaolu, S.S., Adeoye, M.D., Adetoro, R.O., Functionalization of rice husks with ortho-phosphoric acid enhanced adsorptive capacity for anionic dye removal, Chemistry Africa, vol. 3, 2020 , p. 457-467.

[48] Ozturk, N., Kavak, D., Adsorption of boron from aqueous solutions using fly ash: batch and column studies, Journal of Hazardous Materials, vol. B127, 2005, p. 81-88.

[49] Tan, I.A. W., Ahmad, A.L., Hameed, B.H., Adsorption of basic dye on high-surface-area activated carbon prepared from coconut husk: equilibrium, kinetic and thermodynamic studies, Journal of Hazardous Materials, vol. 154, 2008, p. 337-346. 